\title{
Problematic of Legal Protection Against Women after Ratification the Job Creation Act under the ILO Conventions \\ DOI: https://doi.org/10.47175/rissj.v3i1.363
}

\section{| Silvia Fadhilah Patriana |}

\author{
Magister of Law Brawijaya, \\ Malang, Jawa Timur \\ University, Indonesia
}

silviafadila12@gmail.com

\begin{abstract}
It is felt that the overlapping regulations in Indonesia have hampered government programs so far. So that President Jokowi sparked a new regulation, namely the omnibus law with the aim of simplifying regulations in Indonesia so that the omnibus law is believed to be the most relevant solution today. However, this caused a strong reaction by the workers, because it was considered to have the potential to make workers experience marginalization again in the interests of economic development. This research was conducted using a normative juridical approach and intends to explain how legal protection for workers, especially women workers, after the ratification of Law number 11 of 2020 concerning job creation based on International Labour Organization. The results of the research found that no changes were found regarding women's rights in the omnibus law which was also reviewed based on the ILO convention KEYWORDS

women workers; ILO conventions; rights
\end{abstract}

\section{INTRODUCTION}

Since early January, the Indonesian people have been shocked by the official birth of the Omnibus Law as outlined in the PROLEGNAS (National Legislation Program) which was later ratified by the DPR on October 5, 2020. It is said, the Omnibus Law Bill will become a big rule that includes various articles and new norms. to replace the old articles and legal norms. The main objective is none other than to simplify overlapping regulations because so far it is felt to be hampering the investment climate in Indonesia. Therefore, President Jokowi made a new breakthrough, namely by drafting the Omnibus Law. According to Yasonna Laoly as Minister of Law and Human Rights, the existence of the Omnibus Law can absorb labor and also encourage economic growth.. ${ }^{1}$ This thinking is motivated by the decline in economic growth in Indonesia and the high unemployment rate in Indonesia.

In this Job Creation Law, there are 79 laws consisting of 1,253 articles that are trying to be simplified with the aim of being more flexible in responding to changes in the field of employment and investment. The law covers 11 clusters, namely: ${ }^{2}$

1. Simplification, licensing,

2. Investment requirements

3. Employment,

4. Ease, Empowerment, and Protection, .UMK-m, and Cooperatives, .

5. Ease of doing business.

1 Detik news, https://news.detik.com/berita/d-4837745/ini-11-cluster-omnibus-law-uu-cipta-lapangan-kerja. (December, 2019). Accessed 09 Agustus 2021

${ }^{2}$ Sigit Riyanto et al, Catatan Kritis Dan Rekomendasi Terhadap Ruи Cipta Kerja (Yogyakarta: Fakultas Hukum Universitas Gajah Mada, 2020). p.6 
6. Research support and. innovation.

7. Government administration.

8. Application of sanctions.

9. Land acquisition, conversion of agricultural land, land and other related issues

10. National strategy investments and projects,

11. Economic zone.

Since the inception of this law, there have been many pros and cons among the public. The government hopes that this law will be accepted by the public. However, instead of being accepted, the community strongly opposes the existence of this design, especially the workers. They feel that this law prioritizes investment interests above all else, which sacrifices the rights of workers/labourers. Among the 11 Clusters in Law Number 11 of 2020 concerning Employment Creation, this study focuses on the issue of the Employment Cluster where they argue that many of the articles contained in Law Number 13 of 2003 concerning Manpower concern the welfare of workers/labourers. . The articles in the Omnibus Law are very controversial and are considered to have the potential to oppress workers, especially women workers.

This study focuses on the issue of the Labor Cluster regarding the amendments to Articles of Law Number 13 of 2003 concerning Manpower in the Copyright Law related to the rights of laborers, particularly ladies specialists. For illustration, the data circulating amid the method of talking about the law was passed on by the President of the Confederation of Indonesian Exchange Unions (KSPI); to be specific menstrual take off to maternity take off. Apart from the fact that the Omnibus Law on job creation is a new law, the discussion regarding the protection of women is quite interesting because every year the growth of the female workforce also experiences a significant increase. At the present time, women who work as workers/laborers dominate in improving family welfare, to increase income due to the high demands of the current economy. Female workers/laborers are considered cheap laborers who are very profitable so that the current workforce is very abundant. Based on information from the Central Insights Organization, or BPS, the increase in women's work participation in 2020 from the position of 51.8 percent in August 2018 increased by 53.13 percent. $^{3}$

With the changes to several Articles of Law Number 13 of 2003 concerning Manpower in Law Number 11 of 2020 concerning Job Creation, are there any major differences or changes related to labor rights at this time. So, based on the description above, the author raises a problem, namely, How is the legal protection for workers/laborers especially female workers, after the ratification of the Job Creation Law based on the ILO convention? To answer this question, this paper tries to analyze the regulations regarding the security of the rights of ladies laborers after the sanctioning of the Job Creation Law.

\section{RESEARCH METHODS}

In writing this journal, the research method used is a normative juridical research method. Which basically examines the rules and principles of law. ${ }^{4}$ According to Peter Mahmud, normative research is the process of finding a rule of law or legal doctrine in order to answer the legal problems faced. ${ }^{5}$ The approach used in this study uses a statue approach;

\footnotetext{
3 Suhartoyo, "Perlindungan Hukum Bagi Buruh Dalam Sistem Hukum Ketenagakerjaan Nasional," Administrative Law and Governance Journal 2, no. 2 (2019): 326-36, https://doi.org/10.14710/alj.v2i2.326-336.

${ }^{4}$ Soerjono Soekanto and Sri Mamudji, Penelitian Hukum Normatif, Suatu Tinjauan Singkat, Jakarta: Raja Grafindo Persada (Jakarta: Raja Grafindo Persada, 2011). p.7

${ }^{5}$ Mahmud Marzuki dan Peter Mahmud, "Penelitian Hukum,” Jurnal Penelitian Hukum, 2011. p.35
} 
then, the data used is using secondary data originating from sources such as literature, articles and internet sites. In addition, the technique used in this research is to make notes either in the form of direct quotations. Or indirectly obtained from books, internet, or readings related to the discussion discussed in this study. Then the analysis of legal materials in this study was carried out qualitatively; namely doctrinal analysis by explaining, describing, and describing the contents of the research.

\section{RESULTS AND DISCUSSION}

\section{Get to know the concept of the Omnibus Law}

Truly omnibus comes from the Latin word "omnis" which implies numerous. This means that many laws in the sense of implementing regulations are cross-sectoral and can cancel or revoke conflicting provisions. ${ }^{6}$ Concurring to Bryan A Gather in Dark Law, Word reference ninth version: "Omnibus: relating to or a managing with various objects or things at once; counting numerous things or having different purposes"

With the issuance of this one law, it can improve many laws and is expected to be one of the solutions to problems in the economic field, because many laws that regulate and conflict with each other will hinder the acceleration that will be carried out. ${ }^{7}$

This law is also commonly referred to as the universal sweeping law because it contains various topics in it that are intended to amend, trim, or repeal a number of other laws. So it can be concluded that Omnibus Law may be a strategy or concept of making directions by combining a few directions with diverse substances, arrangements, into a big regulation whose function is Umbrella Act. So that when the regulation is promulgated, the consequences are very large; namely, revoking or not, enforcing the regulation, either partially or completely, which has been used so far. ${ }^{8}$ Due to its relatively broad scope, historically, universal sweeping laws have sometimes been used with the aim of producing controversial amendments, leading some academics to view these laws as strongly against democratic principles.

Omnibus law or omnibus bill is one of the laws that emerges from custom, based on the Common law Legal System. ${ }^{9}$ Such as America, Canada, Ireland, Siberia, and Suriname in making regulations. Meanwhile, in countries that adhere to the civil law system, such as Indonesia, it is still foreign or something new with the existence of this omnibus law.

On that is considered contradictory or overlapping. Due to the many regulations or rules that exist in Indonesia, it causes uncertainty and legal uncertainty for the community. So, according to Jokowi, the existence of the Omnibus law is one way out and a very relevant solution to solve existing problems.

\section{Problems with the legal protection of women workers after the enactment of} Law Number 11 of 2020 concerning Job Creation Based on the ILO Convention.

Legal protection for workers is a frame of fulfillment of fundamental rights that are inherent and protected by the constitution, which has been regulated in Article 28 Letter D

\footnotetext{
${ }^{6}$ Amirudin ilmar, Kepemerintahan Yang Bertanggung Jawab: Melalui Penerapan Prinsip Akuntabilitas Pemerintahan. (Makassar: Phinata Media, 2020). p.35

7 Achmad Wahyudin, "Konsepsi Implementasi Omnibus Law Pada Sistem Perundang-Undangan" (Semarang, 2019), Accessed $\quad$ Agustus 2020 , https://www.academia.edu/41537217/MAKALAH_OMNIBUS_LAW.

${ }^{8}$ https://business-law.binus.ac.id/2019/10/03/memahami-gagasan-omnibus-law/. Diakses 14 Agustus 2020

${ }^{9}$ Jimly Asshiddiqie, "UU TERPADU (Omnibus Law)," Ceramah, Accessed Agustus 42020 , https://www.academia.edu/41009264/UU_TERPADU_Omnibus_Law_.
} 
of the 1945 Constitution of the Republic of Indonesia, that states " Everybody has the proper to work and get emolument and treatment. reasonable and fitting in an business relationship". This protection aims to guarantee the basic rights of workers/laborers and also to provide a sense of justice and protection for workers/laborers as well as to fulfill the mandate of the 1945 Constitution, namely in carrying out development for all Indonesian people, and to improve the dignity of workers, and self-esteem. workers or laborers and create a prosperous, just and prosperous society.

According to Philipus M. Hadjon in his book, he defines legal protection as a form of protection of the nobility, and worth, as well as the acknowledgment of human rights had by lawful subjects based on the arrangements of legal authority. ${ }^{10}$

Regarding legal protection, Philipus M. Hadjon always associated it with power. In this case, the strongest are the employers and the weak are the workers. Legal protection for workers/labor is very necessary ${ }^{11}$ considering their very weak position, especially female workers.

"Workers/laborers are the backbone of the company" This saying has an important role. Where without workers/labor it is impossible for a company to run and participate in a development. ${ }^{12}$

So it is very reasonable if there is legal protection for workers through the protection, maintenance, and development of their welfare ${ }^{13}$ Current female workers/laborers dominate and contribute to improving family welfare by working in factories or companies to increase their income due to the current high economic demands. Female workers/laborers are considered cheap laborers who are very profitable, so the workforce is currently very abundant.

The law serves as a protector of human interests. In order for an interest to be protected, the law must be implemented. In terms of implementing the law, it must be able to provide legal certainty (Rechtssicherheit), benefit (Zweckmassigkeit), and justice (gerechtigkeit). Don't let the law causes unrest in the community ${ }^{14}$ In this case, it relates to the working relationship of workers/labourers, especially female workers/labourers.

Indonesia as a country that applies the concept of a welfare state, must be active in organizing the welfare and prosperity of its citizens, as well as for the benefit of all the people. ${ }^{15}$

Related to legal protection for workers, it is also regulated in Article 5 of Law Number 13 of 2003, which provides protection that every worker has the right and also has the same opportunity to obtain or obtain work and also a decent living without any differences in rights and obligations, sexual orientation, ethnicity, race. , religion and political belief system in agreement with the interface and capacities of the workforce concerned, counting break even with treatment of laborers with inabilities or disabilities. ${ }^{16}$

In order to protect female workers/labourers, the Indonesian government made other legal regulations that aim to protect female workers/laborers by issuing Law Number 13 of

\footnotetext{
${ }^{10}$ Philipus M Hadjon, Perlindungan Hukum Bagi Masyarakat Indonesia (Surabaya: Bima Ilmu, 1987). p.35

${ }^{11}$ Zainal Asikin, Dasar-Dasar Hukum Perburuhan (Jakarta: Rajawali Pers, 2012). p.15

12 Ibid

13 Shinta Kumala Sari, "Perlindungan Hukum Bagi Pekerja Dalam Perjanjian Kerja Waktu Tertentu (PKWT)," Digital Library (Universitas sebelas maret, 2011), https://digilib.uns.ac.id.

${ }^{14}$ Sudikno Mertokusumo, Mengenal Hukum: Suatu Pengantar (Yogyakarta: liberty, 1999). p.37

15 Abu Daud Busroh, Ilmu Negara (Jakarta: Bumi Aksara, 2015).Hal.55

16 Suhartoyo, "Perlindungan Hukum Bagi Buruh Dalam Sistem Hukum Ketenagakerjaan Nasional," Administrative Law and Governance Journal 2, no. 2 (2019): 326-36, Accessed Agustus 16, 2020, doi: https://doi.org/10.14710/alj.v2i2.326-336.
} 
2003 which controls the security of female laborers, which was later amended in Law No.11 of 2020, which regulates job creation for the welfare of workers/laborers, especially women. To facilitate this discussion, the researcher will start this discussion in the following table:

Tabel 1. Rights, female workers/labourers In Indonesia

\begin{tabular}{|c|c|c|c|}
\hline No. & $\begin{array}{l}\text { ARTICLE OF LAW } \\
\text { NUMBER 13 OF } 2003 \\
\text { CONCERNING } \\
\text { MANPOWER }\end{array}$ & FORM OF PROTECTION & $\begin{array}{l}\text { CHANGES IN LAW } \\
11 / 2020 \\
\text { CONCERNING JOB } \\
\text { CREATION }\end{array}$ \\
\hline 1 & $\begin{array}{l}\text { Special Facility Rights at } \\
\text { certain hours } \\
\text { Article } 76\end{array}$ & $\begin{array}{l}\text { For female workers who are less } \\
\text { than } 18 \text { (eighteen) years old are } \\
\text { prohibited from being employed } \\
\text { from } 23.00 \text { to } 07.00\end{array}$ & No changes \\
\hline 2 & $\begin{array}{l}\text { Protection Rights During } \\
\text { Pregnancy } \\
\text { Article } 76 \text { Paragraph } 2\end{array}$ & $\begin{array}{l}\text { Female workers have the right not } \\
\text { to work if they are pregnant which } \\
\text { according to the doctor's statement } \\
\text { is dangerous for the womb and for } \\
\text { themselves if they work from } 23.00 \\
\text { to } 07.00\end{array}$ & No changes \\
\hline 3 & $\begin{array}{l}\text { Menstrual Leave Rights } \\
\text { Article } 81 \text { Paragraph 1, }\end{array}$ & $\begin{array}{l}\text { For female workers/laborers who } \\
\text { feel wiped out amid feminine cycle } \\
\text { and inform the business person, } \\
\text { they are not obliged to work on the } \\
\text { primary and moment day of } \\
\text { monthly cycle. }\end{array}$ & No changes \\
\hline 4 & $\begin{array}{l}\text { Maternity and maternity } \\
\text { leave rights } \\
\text { Article } 82 \text { Paragraph } 1 \text {, }\end{array}$ & $\begin{array}{l}\text { Female workers/laborers have the } \\
\text { correct to rest for } 1.5 \text { (one and a } \\
\text { half) months some time recently } \\
\text { and after giving birth concurring to } \\
\text { the calculation of the obstetrician or } \\
\text { maternity specialist. }\end{array}$ & No changes \\
\hline 5 & $\begin{array}{l}\text { Maternity leave rights } \\
\text { Article } 82\end{array}$ & $\begin{array}{l}\text { If the female worker/labourer } \\
\text { experiences a miscarriage, she is } \\
\text { entitled to a break for } 1.5 \text { (one and } \\
\text { a half) months or in understanding } \\
\text { with a certificate issued by the } \\
\text { obstetrician or maternity specialist. }\end{array}$ & No changes \\
\hline 6 & Maternity fee rights & $\begin{array}{l}\text { The obligation of companies that } \\
\text { have more than } 10 \text { workers/labor or } \\
\text { pay a minimum wage of Rp. } \\
1,000,000 \text { to include all of its } \\
\text { workforce in the BPJS Health } \\
\text { program }\end{array}$ & $\begin{array}{l}\text { (Regulated in Law } \\
\text { Number } 3 \text { of } 1992 \\
\text { concerning Social } \\
\text { Security and } \\
\text { Government } \\
\text { Regulation Number } 14 \\
\text { of } 1993 \text { concerning the } \\
\text { Implementation of the } \\
\text { Worker's Social } \\
\text { Security Program) }\end{array}$ \\
\hline
\end{tabular}




\begin{tabular}{|l|l|l|l|}
\hline $\mathbf{7}$ & Breastfeeding Rights & $\begin{array}{l}\text { Female workers/labourers are } \\
\text { entitled to appropriate opportunities } \\
\text { during their working hours for } \\
\text { female workers/laborers whose } \\
\text { children are still breastfeeding. }\end{array}$ & No changes \\
\hline $\mathbf{8}$ & $\begin{array}{l}\text { Prohibition of layoffs due to } \\
\text { marriage, pregnancy and } \\
\text { childbirth }\end{array}$ & $\begin{array}{l}\text { Female specialists may not be } \\
\text { subject to end of work or end of } \\
\text { work on the grounds of pregnancy, } \\
\text { childbirth, premature delivery, or } \\
\text { breastfeeding their infant. }\end{array}$ & $\begin{array}{l}\text { This article discusses } \\
\text { changes to the Job } \\
\text { Creation Law but does } \\
\text { not change the } \\
\text { previous substance }\end{array}$ \\
\hline
\end{tabular}

Based on the explanation of the table above, it can be seen that there is no change in the content or substance of the article, regarding the provision of protection for female workers/laborers in Law Number 11 of 2020 concerning Job Creation. So that it does not have an impact on the rights previously regulated in the Manpower Act.

Although the regulation has been regulated in the Manpower Law, in fact, in Indonesia there are still many female workers/laborers who have not yet received their rights. Either because the workplace has not implemented regulations on the rights of women workers/laborers or maybe because women workers/labourers do not know what rights they should receive. So that. here the government makes policies to maintain and also regulate the rights of women workers/laborers with the support of the International Convention, Labor Organization (ILO).

Regarding the protection of women workers, especially women's rights, it is also regulated in the International Labor Organization (ILO) Conventions. The ILO as an international labor organization continues to strive to always encourage the creation of decent, productive, free, safe and dignified work opportunities for women and men.

The ILO conventions are international treaties that must be ratified by its member states. One of them is that Indonesia is the first and fifth Asian country in the world that has ratified 17 conventions. ${ }^{17}$ The ILO in Indonesia has several tasks in terms of assisting the government, employers, workers and their organizations (Tripartite) to implement the conventions of the ILO (International Labor Organization), in particular the conventions that have been ratified by Indonesia.

There are several ILO standard references that have an impact on women workers, namely as follows: ${ }^{18}$

a) Regarding Equality of Wages;

b) Regarding acts of discrimination in work and also positions;

c) Pregnancy protection;

d) Work and family responsibilities.

There are 4 (four) main ILO Conventions that prohibit acts of discrimination based on sex and promote equality, namely: ${ }^{19}$ Equal Pay Convention, 1951 (No. 100), Discrimination (Employment and Occupation) Convention, 1958 (No. 111), Workers with Family Responsibilities Convention, 1981 (No. 156), and Maternity Protection Convention, 2000 (No. 183).

\footnotetext{
${ }^{17}$ Fakta ILO, “International Labour Organization,” accessed November 24, 2021, http://www.ilo.org/public/indonesia/\%0Aregion/asro/jakarta/download/faktailojkt.pdf.

${ }^{18}$ ILO Ind, Konvensi-Konvensi ILO Tentang Kesetaraan Gender Di Indonesia (Jakarta: ILO Publisher, 2006). p.4

${ }^{19}$ Ibid, p.6
} 
Of the 4 (four) Conventions, the authors will describe below whether or not they have complied with the legal norms required by women workers in Indonesia.

\section{Equal Pay Convention, 1951 (No.100),}

Indonesia has ratified this Convention with Law Number 80 of 1957. In the ILO Convention Number 100 of 1951 concerning Wages, which states that there is a prohibition on egregation based on sex/gender within the working environment. This form of discrimination includes diverse pay for work of break even with esteem. ${ }^{20}$ Basically, equal pay for workers/labor has been embedded in the constitution. One of them is contained in Article 28D, passage (2) of the 1945 Structure, which states that everybody has the proper to work and get remuneration or wages as well as reasonable and legitimate treatment in an business relationship. In addition, the previous Manpower Law was regulated in Article 88 paragraph (1) and paragraph (2) which later in Law Number 11 of 2020 concerning job creation, changed wages. And there is also an implementing regulation in PP No. 36 of 2021 which aims to realize the rights of workers to a decent living for humanity. Then there are also rules in Article 11 of Law Number 7 of 1984 concerning the approval of the tradition, concerning the disposal of all shapes of segregation against ladies. In the mean time, there are directions related to sanctions for entrepreneurs who discriminate against wages as stated in PP No. 8 of 1981 Article 31.

Working at a decent and guaranteed wage is part of human rights, because everyone has the same rights and is also the same in working in accordance with applicable labor regulations. So it can be concluded that the norms in Indonesia are in accordance with this convention, although in practice there is still wage discrimination against female workers/laborers who are always differentiated from men. Referring to the provisions above, this gap should not have occurred. Because the regulation clearly stipulates that employers provide a decent salary or wages according to the type of work, without having to discriminate or discriminate against workers, especially women. Thus, if female workers/laborers do the same work as men, it is proper that the salary or wages received should be the same. ${ }^{21}$

Discrimination Convention in Employment and Occupation, 1958 (No.111),

This Convention has been ratified in Indonesia through Law Number 7 of 1984 concerning the disposal of all shapes of segregation against ladies. At that point, with the approval of the ILO Convention No. 111 concerning anti-discrimination of positions and occupations, which has been approved in Law number 21 of 1999. In expansion, Articles 5 and 6 of the Labor Law state that each laborer has the correct to get or get break even with treatment without boss segregation.

Workers with Family Responsibilities Convention, 1981 (No.156),

Until now, Indonesia has not ratified the convention, but several articles of the Manpower Law, such as Article 99, Article 100 and Article 157, have regulated the existence of welfare guarantees for every worker or worker and their family. Then, in Article 157 of the Job Creation Law, it changes the wage component by inserting Article 157A, but still focuses on family welfare.

\footnotetext{
${ }^{20}$ Konvensi ILO No. 100 Tahun 1951 tentang Upah yang sama bagi Pekerjaan Bernilai Sama bagi Pria dan Wanita yang diratifikasi melalui Undang-undang No. 80 Tahun 1957 dan Konvensi ILO No. 111 Tahun 1958 tentang Diskriminasi dalam Pekerjaan dan Jabatan yang diratifikasi melalui UU No. 21 Tahun 1999

${ }^{21}$ Annida Addiniaty, “Lemahnya Perlindungan Hukum Bagi Buruh Wanita,” Jurnal Rechts Vinding 3 (2013).
} 
Maternity Protection Convention, 2000 (No.183),

Female workers/labourers have an innate nature that must receive special protection, namely during pregnancy and breastfeeding their children. In terms of maternity protection, the ILO Maternity Protection Convention, 2000, has not yet been ratified by Indonesia. However, the Manpower Law Number 13 of 2003 has regulated the protection of women's reproduction which is regulated in Articles 81 to 83 whose content or substance is not changed in Law Number 11 of 2020 concerning Job Creation.

Pregnant, giving birth, and breastfeeding children as regulated in Article 10 Paragraph (1) of Law Number 39 of 1999 concerning Human Rights, which states that everyone has the correct to make a family, and to proceed descendant through lawful marriage. On that basis, the state of Indonesia in particular has respected and protected workers/laborers, especially women, for their productive rights. Although the regulation has been regulated in several legal instruments, there are still violations committed by the company against female workers/laborers. ${ }^{22}$

Then regarding Protection During Maternity Leave (Maternity and Maternity Leave) in Article 82 of Law Number 13 of 2003 concerning Employment for female workers or workers, they have the right to get or rest for 1.5 months before giving birth to children and get 1.5 months, after giving birth. For this reason, the worker or laborer must notify the head of the company, either orally or in writing, no later than 1.5 months before the estimated birth. After giving birth to a working family or female worker, she is also obliged to notify the birth of her child, within seven days after the birth. Provisions as shown in this table are deemed inefficient when referring to the provisions of the ILO Maternity Protection Convention, 2000 (No. 183,) which provides the right to 14 weeks of maternity leave. So here according to the author, in order to provide protection for female workers/labourers, Indonesia must ratify this convention.

The purpose of the existence of legal protection for workers / laborers, especially women is to provide protection from the arbitrariness of entrepreneurs and also to create a harmonious atmosphere in the company that can be carried out in accordance with existing rules in industrial relations.

This protection is intended to provide certainty of workers/labor rights related to work norms which include working time, rest (leave). Security of specialists here is aiming to ensure the essential rights of specialists or laborers conjointly to ensure break even with openings, as well as to supply treatment without segregation on any premise to realize the welfare of specialists or workers and their families, as long as taking under consideration advancements within the working environment. commerce world. ${ }^{23}$

From the explanation above, both normatively, the Convention and the existing regulations, namely the Manpower Law and the Post-Enforcement Copyright Law, have been fulfilled, which only includes additional laws in them without changing the substance of this article.

The implementation of this ILO convention is a form of implementation and protection of access for women workers/laborers which is realized by empowering women, as well as eliminating discrimination against women in various fields that can be carried out by the government through the legal field. ${ }^{24}$

\footnotetext{
${ }^{22}$ Ni putu pranasari dan Ni luh gede astariyani, "Hukum Pekerja Wanita Terhadap Hak Reproduktif," Jurnal Kertha Semaya 3, no. 3 (2015).

${ }^{23}$ Riris Ardhanariswari, "Perlindungan Hak Asasi Manusia Bagi Tenaga Kerja Perempuan Dalam Prespektif Sistem Hukum Indonesia Abad-21," Padjajaran Jurnal Ilmu Hukum jilid XXXI (2009). p.97

${ }^{24}$ Sinta Ulin, "Pekerja Wanita Di Perusahaan Dlam Prespektif Hukum Dan Gender," Jurnal Equality 10, no. 2 (2005).
} 
It is the responsibility of the government and also the ministry of manpower to pay attention to the fate of female workers which can be provided by providing information through counseling or direct advocacy to female workers/laborers.

The Government of Indonesia should oversee the implementation of the ILO conventions that have been ratified by Indonesia, which are as follows:

a) In this case, the government is asked to report on the implementation of ILO conventions and recommendations on a regular basis, which is based on the ILO Reporting Obligation standard;

b) Conventions as well as ILO recommendations with reported implementation on a time, annual, bi-annual, and five-year basis;

c) Reports submitted to the ILO are consulted, or communicated in advance to representatives of Tripartite Indonesia. ${ }^{25}$

In addition to the government and the International Labor Organization (ILO), efforts to protect women workers/laborers can also be carried out by labor organizations in Indonesia in particular. With direct support from the Indonesian government, these organizations can carry out various activities and breakthroughs as a form or step, to protect women workers, one of which is the establishment of a Women's Labor School by the Federation of CrossFactory Workers in Indonesia.

\section{CONCLUSION}

So from the explanation above it can be concluded. Basically, the rights of women workers/laborers when referring to the Conventions of the International Labor Organization, both from a normative point of view, have been fulfilled between the Convention and the existing regulations, namely Employment. Law, and after the enactment of the Labor Copyright Law, which only includes additional laws in it, without changing the substance of the articles. The protection of women workers/laborers as described above has provided good protection for women workers. Although in practice in the field there are still employers who neglect their obligations to their workers.

\section{REFERENCES}

Addiniaty, Annida. (2013). "Lemahnya Perlindungan Hukum Bagi Buruh Wanita.” Jurnal Rechts Vinding.

Ardhanariswari, Riris. (2009). "Perlindungan Hak Asasi Manusia Bagi Tenaga Kerja Perempuan Dalam Prespektif Sistem Hukum Indonesia Abad-21." Padjajaran Jurnal Ilmu Hukum jilid XXXI

Asshiddiqie, Jimly. "UU TERPADU (Omnibus Law)." Ceramah. Accessed August 4, 2020. https://www.academia.edu/41009264/UU_TERPADU_Omnibus_Law_.

Asikin .Zainal. (2012).Dasar-Dasar Hukum Perburuhan. Jakarta: Rajawali Pers, Ilmar. Amirudin. (2020). Kepemerintahan Yang Bertanggung Jawab: Melalui Penerapan Prinsip Akuntabilitas Pemerintahan. Makassar: Phinata Media.

Daud Busroh, Abu. (2015). Ilmu Negara. Jakarta: Bumi Aksara.

Sigit Riyanto, et al (2020). Catatan Kritis Dan Rekomendasi Terhadap Ruu Cipta Kerja.. Yogyakarta: Fakultas Hukum Universitas Gajah Mada.

Hidayat, Faiq. (2019). "Ini 11 Cluster Omnibus Law UU Cipta Lapangan Kerja." Detik news, 2019. https://news.detik.com/berita/d-4837745/ini-11-cluster-omnibus-law-uucipta-lapangan-kerja.

25 Ibid 
ILO Ind. (2006). Konvensi-Konvensi ILO Tentang Kesetaraan Gender Di Indonesia. Jakarta: ILO Publisher.

Koto, I., \& Hanifah, I. (2021). The Legal Protection for Female Workers in the Perspective of Islamic Law and Law No. 11 Year 2020 on Job Creation. Randwick International of Social Science Journal, 2(4), 524-534. https://doi.org/10.47175/rissj.v2i4.333

Kumala Sari, Shinta. (2011) "Perlindungan Hukum Bagi Pekerja Dalam Perjanjian Kerja Waktu Tertentu (PKWT)." Digital Library. Universitas Sebelas Maret, https://digilib.uns.ac.id.

Mahmud Marzuki, Peter. (2011). Penelitian Hukum. Jurnal Penelitian Hukum,

Mertokusumo, Sudikno. (1999). Mengenal Hukum: Suatu Pengantar. Yogyakarta: liberty.

Ni luh gede astariyani, Ni putu pranasari. (2015). "Hukum Pekerja Wanita Terhadap Hak Reproduktif.” Jurnal Kertha Semaya 3, no. 3

Philipus M Hadjon. (1987). Perlindungan Hukum Bagi Masyarakat Indonesia. Surabaya: Bima Ilmu.

Soekanto, Soerjono, and Sri Mamudji. (2011). Penelitian Hukum Normatif, Suatu Tinjauan Singkat. Jakarta : .Raja Grafindo Persada. Jakarta: Raja Grafindo Persada.

Suhartoyo. (2019). "Perlindungan Hukum Bagi Buruh Dalam Sistem Hukum Ketenagakerjaan Nasional." Administrative Law and Governance Journal 2, no. 2: 326-36. https://doi.org/10.14710/alj.v2i2.326-336.

Santo, Paulus Aluk. "Memahami Gagasan Omnibus Law." Copyright (C) BINUS UNIVERSITY. All rights reserved, 2019. Accessed August 4, 2020. https://businesslaw.binus.ac.id/2019/10/03/memahami-gagasan-omnibus-law/.

Susiana, Sali. (2017). "Perlindungan Hak Pekerja Perempuan Dalam Perspektif Feminisme.” Aspirasi: Jurnal Masalah-Masalah Sosial 8, no. 2; 207-22.

Ulin, Sinta. (2005). "Pekerja Wanita Di Perusahaan Dlam Prespektif Hukum Dan Gender." Jurnal Equality 10, no. 2.

Undang-undang Dasar Negara Republik Indonesia Tahun 1945

Undang-undang Nomor 11 Tahun 2020, Tentang Cipta kerja

Undang-Undang Nomor 13 Tahun 2013, Tentang Ketenagakerjaan

PP Nomor 36 Tahun 2021, Tentang Pengupahan

Undang-undang Nomor 39 Tahun 1999, Tentang Hak Asasi Manusia (HAM)

Wahyudin, Achmad. (2019). "Konsepsi Implementasi Omnibus Law Pada Sistem Perundang-Undangan.” Semarang,. Accessed Agust 4, 2020. https://www.academia.edu/41537217/MAKALAH_OMNIBUS_LAW.

Zsazya. "Omnibus Law Dan Rencana Penerapannya Di Indonesia." Accessed August 15, 2020. https://www.online-pajak.com/tentang-pph-final/omnibus-law. 